\title{
Bleomycin-induced Flagellate Dermatitis: a Case Report
}

\author{
Beatrice TONIN ${ }^{1 *}$, Davide GEAT ${ }^{1}$, Giampiero GIROLOMONI ${ }^{1}$ \\ ${ }^{1}$ Department of Medicine, Section of Dermatology, University of Verona, Verona, Italy \\ Correspondence: Beatrice Tonin, E-mail: beatrice.tonin18@gmail.com
}

UDC 616.5-002-02:616-006.44-085.38

\begin{abstract}
Flagellate dermatitis represents a unique cutaneous eruption associated with several causes, including treatment with certain chemotherapeutic agents, ingestion of toxins and rheumatologic conditions like adult-onset Still's disease and dermatomyositis. We present the case of a 35-year-old woman with stage IIA Hodgkin lymphoma who was treated with the ABVD chemotherapy regimen (doxorubicin, bleomycin, vinblastine and dacarbazine). During the third cycle of chemotherapy, she developed multiple linear erythematous macules and hyperpigmentation in a striking flagellate-like pattern localized on the upper chest, submammary folds, neck and upper part of the back. The lesions resolved completely within three months after the withdrawal of bleomycin. Clinicians should be aware of this distinctive cutaneous toxicity in patients receiving bleomycin combination chemotherapy.
\end{abstract}

Key words: Bleomycin; Drug-Related Side Effects and Adverse Reactions; Erythema; Antineoplastic Combined Chemotherapy Protocols; Hodgkin Disease; Hyperpigmentation

\section{Introduction}

Bleomycin is a cytotoxic chemotherapeutic agent used in the treatment of testicular and ovarian germ cell tumors, lymphomas and squamous cell carcinomas of the head and neck. It is also used for pleurodesis in recurrent malignant pleural effusion, and intralesional bleomycin injections are currently used by dermatologists to treat a number of cutaneous conditions including therapy-resistant verrucae vulgaris, keloids and hypertrophic scars. Beside the well-known pulmonary toxicity, bleomycin is also associated with several mucosal and cutaneous complications. Bleomycin skin toxicity includes flagellate erythema, alopecia, nail bed changes, inflamed nodules on fingers, palmar plantar erythema, eczematous changes, erythematous plaques on knees and elbows, digital gangrene, Raynaud's phenomenon and sclerodermoid lesions $(1,2)$.

\section{Case report}

A 35 year-old Caucasian woman presented to our clinic complaining of a "troublesome" dermatitis of the trunk and neck that had been present for about one month. The patient's medical history was significant for Ann Arbor stage IIA Hodgkin lymphoma of nodular sclerosing subtype, with supraclavicular and extensivemediastinal lymph node involvement. She had no systemic symptoms such as night sweats, weight loss or fever. ABVD chemotherapy regimen (which includes doxorubicin, bleomycin, vinblastine and dacarbazine) was chosen as first-line therapy. The cutaneous lesions appeared during the patient's third cycle of chemotherapy. Routine blood investigations revealed slightly elevated ESR of $27 \mathrm{~mm} / \mathrm{h}$ while the patient's serologies were negative for HIV and hepatitis B and C viruses.

On physical exam, multiple erythematous-brownish macules with linear distribution were localized on the upper chest, neck and upper part of the back (Figure 1 A and B). A crisscrossing flagellate hyperpigmentation was observed in the submammary folds. All lesions were intensely itchy; there was no evidence of mucosal involvement.

Based on the history and characteristic distribution of the rash, the diagnosis of bleomycin-induced flagellate dermatitis was made. A therapy with high potency topical steroids and oral antihistamines was initiated, which resulted in prompt reduction of the itch but persistence of the skin lesions. Bleomycin was hence later suspended by the hematolo- 


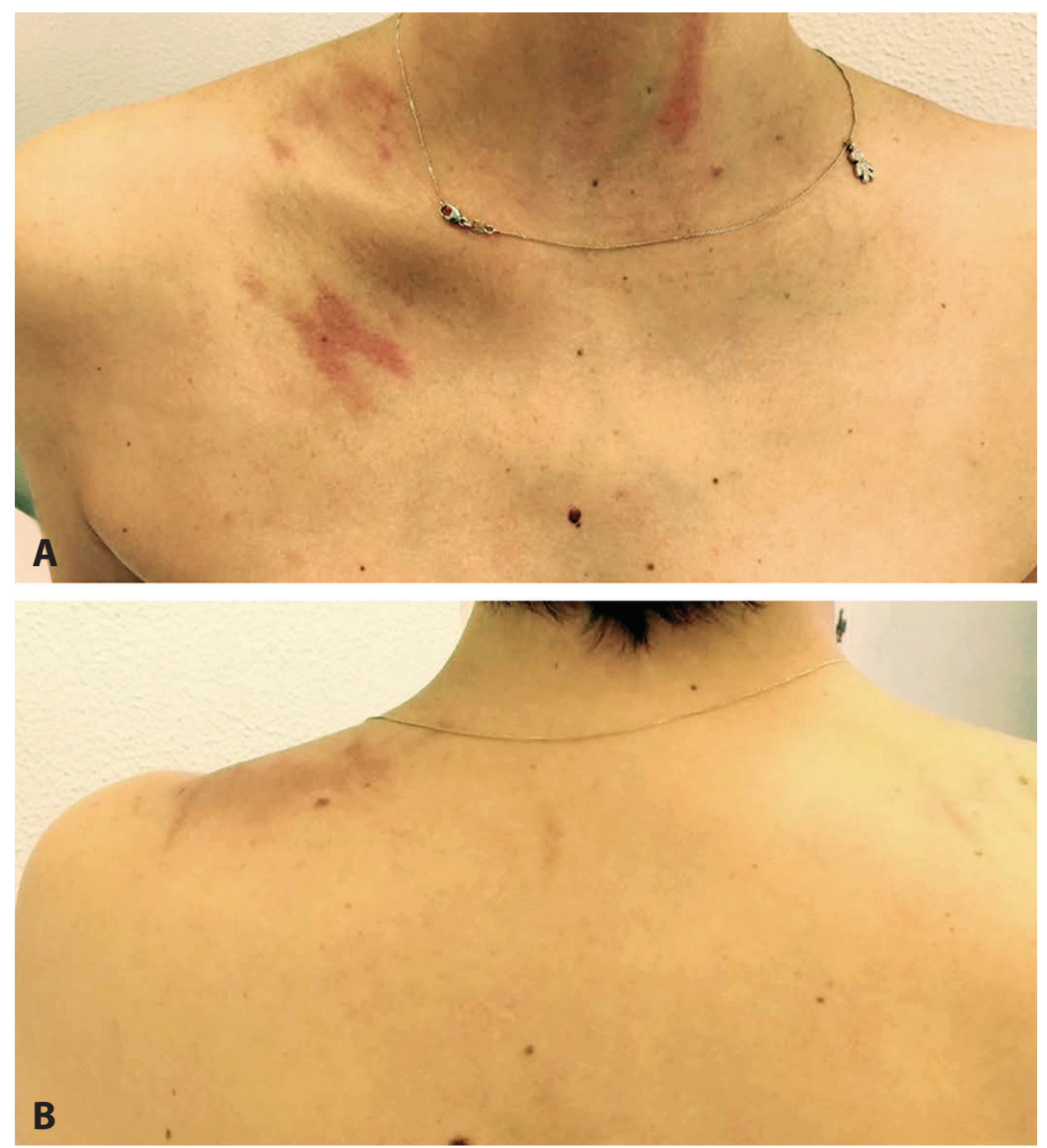

Figures 1 A and B. Erythematous-brownish linear streaks in a flagellate-like pattern on the upper part of the trunk and neck

gists and, three months after its discontinuation, complete resolution of the dermatitis was achieved.

\section{Discussion}

Flagellate dermatitis (from the Latin flagellum) is a cutaneous eruption characterized by erythematous linear streaks in a typical whip-like pattern. Flagellate dermatitis can be caused by a plethora of conditions (3): mechanical causes (i.e. true flagellation because of torture, abuse, religious punishment, sadomasochism, dermatitis artefacta), chemotherapy (due to bleomycin, peplomycin, docetaxel, doxorubicin, cisplatin, trastuzumab, bendamustine), rheumatological diseases (dermatomyositis, adult-onset Still's disease), toxins (shittake mushroom ingestion, Cnidarian stings, Paederus and other insects), other pruritic dermatoses (dermographism, excoriations in pruritic conditions, phytophotodermatitis, poison ivy dermatitis), human immunodeficiency virus, hypereosinophilic syndrome, Chikungunya fever, or it can be idiopathic. Flagellate dermatitis after bleomycin was first described by Moulin et al. in 1970 as bleomycin-induced linear hyperpigmentation (4). Bleomycin is an antineoplastic antibiotic derived from Streptomyces verticillus, first described in Japan by Umezawa in 1966 (5). It acts by generating activated oxygen-free rad- 
icals which cause single and double-stranded DNA break and subsequent cell death.

Bleomycin is the most common chemotherapeutic agent to cause flagellate dermatitis, which is observed in $8 \%$ to $22 \%$ of treated patients (6) and is independent of the route of administration (including after intralesional injection) (7). The skin eruption can first appear 2 hours after the first dose to several weeks after multiple doses (2). While this was previously thought to be dose-dependent, arising in patients with total doses above 100 units, it was later observed after doses as low as 5 units (6). Bleomycin-induced flagellate dermatitis is generally (but now always) preceded by generalized itching (6) and predominantly involves the upper thorax and back. Patch tests with bleomycin are negative, while histological features associated with flagellate dermatitis lack specificity. The most commonly encountered findings include inconspicuous epidermal or spongiotic dermatitis with superficial lymphocytic infiltrates and/or neutrophilic or eosinophilic granulocytes, dermal edema, melanophages in the papillary dermis, epidermal hyperpigmentation (6). In our case, the characteristic morphology of the lesions and the hyperpigmented evolution pointed toward the diagnosis of flagellate dermatitis. Other causes of flagellate dermatitis (e.g. dermatitis factitia) were excluded and, among the drugs our patient had been treated with before developing the skin eruption, bleomycin was the only one associated with flagellate erythema.

Proposed mechanisms which may explain this condition include microtrauma on bony prominence skin areas (6), inflammatory oncotaxis and reduced epidermal turnover - which results in prolonged contact between melanocytes and keratinocytes. It should come as no surprise that bleomycin toxicity involves the skin (along with the lung), sincethe hydrolase which degrades bleomycin is less expressed in the skin and lung compared to other organs, thus resulting intoxic cutaneous concentration of bleomycin (6). Furthermore, scratching may trigger skin vasodilation which also favors local drug accumulation (6). This is consistent with our findings, where the skin lesions were mostly located in skin areas which were accessible to scratching, while the central upper back was relatively spared. Cessation of bleomycin is recommended in severe forms, while systemic antihistamine and steroids (topical or short courses of systemic steroids) may be warranted for symptomatic relief (8). Bleomycin-induced flagellate dermatitis is self-limited and generally recedes within 6 months from the discontinuation of the drug (9). Temporary or, more rarely, permanent hyperpigmentation in the affected area may ensue. Re-exposure to bleomycin is best avoided as it may trigger the recurrence of the skin eruption. The importance of being aware of the existence of this rare cutaneous adverse effect of bleomycin should be underlined because the risk of recurrence is also present for dermatological intralesional use.

\section{References}

1. Cortina P, Garrido JA, Tomas JF, Unamuno P, Armijo $M$. 'Flagellate' erythema from bleomycin: with histopathological findings suggestive of inflammatory oncotaxis. Dermatológica. 1990;180(2):106-9.

2. Chen YB, Rahemtullah A, Breeden E, Hochberg EP. Bleomycin-induced flagellate erythema. J Clin Oncol. 2007;25(7):898-900.

3. Bhushan P, Manjul P, Baliyan V. Flagellate dermatoses. Indian J Dermatol Venereol Leprol. 2014;80(2):149-52.

4. Moulin G, Fière B, Beyvin A. Pigmentation cutanee par la bleomycine. Bull Soc Fr Dermatol Syphiligr. 1970;77(2):293-6.

5. Umezawa $\mathrm{H}$. Bleomycin and other antitumor antibiotics of high molecular weight. Antimicrob Agents Chemother (Bethesda). 1965;5:1079-85.

6. Ziemer M, Goetze S, Juhasz K, Elsner P. Flagellate dermatitis as a bleomycin-specific adverse effect of cytostatic therapy: a clinical-histopathologic correlation. Am J Clin Dermatol. 2011;12(1):68-76.

7. Abess A, Keel DM, Graham BS. Flagellate hyperpigmentation following intralesional bleomycin treatment of verruca plantaris. Arch Dermatol. 2003;139(3):337-9.

8. Mota GD, Penna AM, Soares RC, Baiocchi OC. Bleomycin-induced flagellate dermatitis. Rev Bras Hematol Hemoter. 2014;36(4):297-9.

9. Mowad CM, Nguyen TV, Elenitsas R, Leyden JJ. Bleomycin induced flagellate dermatitis: a clinical and histopathological review. Br J Dermatol. 1994;131(5): 700-2. 


\section{Flagelatni dermatitis izazvan bleomicinom - prikaz slučaja}

\section{Sažetak}

Flagelatni dermatitis predstavlja jedinstvenu kožnu erupciju povezanu nekolikim uzrocima, uključujući lečenje određenim hemioterapijskim agensima, unošenje toksina i reumatološka stanja poput Stilove bolesti kod odraslih i dermatomiozitisa. Predstavljamo slučaj 35-godišnje žene sa Hočkinovim limfomom IIA stadijuma koja je lečena ABVD režimom hemioterapije (doksorubicin, bleomicin, vinblastin i dakarbazin). Tokom trećeg ciklusa hemioterapije, kod nje su se razvile vi-

\begin{abstract}
šestruke linearne eritematozne makule i hiperpigmentacija upečatljivog oblika nalik na tragove biča, lokalizovane na gornjem delu grudnog koša, u podmamarnim naborima, na vratu i gornjem delu leđa. Lezije su u potpunosti nestale u periodu od tri meseca nakon prekida terapije bleomicinom. Kliničari bi trebalo da obrate pažnju na ovu karakterističnu kožnu toksičnost kod pacijenata tretiranih kombinovanom hemioterapijom koja uključuje bleomicin.
\end{abstract}

Ključne reči: Bleomicin; Neželjena dejstva i reakcije izazvane lekovima; Eritem; Antineoplastični protokoli kombinovane hemoterapije; Hočkinova bolest; Hiperpigmentacija

Received 16.01.2020.

Accepted 31.03.2020. 